This is an electronic reprint of the original article. This reprint may differ from the original in pagination and typographic detail.

Author(s): Lähdesmäki, Tuuli

Title: $\quad$ Narrativity and intertextuality in the making of a shared European memory

Year: $\quad 2017$

Version:

Please cite the original version:

Lähdesmäki, T. (2017). Narrativity and intertextuality in the making of a shared European memory. Journal of Contemporary European Studies, 25(1), 57-72. https://doi.org/10.1080/14782804.2016.1159544

All material supplied via JYX is protected by copyright and other intellectual property rights, and duplication or sale of all or part of any of the repository collections is not permitted, except that material may be duplicated by you for your research use or educational purposes in electronic or print form. You must obtain permission for any other use. Electronic or print copies may not be offered, whether for sale or otherwise to anyone who is not an authorised user. 


\section{Narrativity and Intertextuality in the Making of a Shared European Memory}

Author: Tuuli Lähdesmäki, Academy Research Fellow (PhD, DSocSci) and Adjunct Professor

Affiliation:

Department of Art and Culture Studies, University of Jyväskylä, Finland.

Mailing address:

Tuuli Lähdesmäki

Department of Art and Culture Studies

P.O. Box 35

40014 University of Jyväskylä

Finland

E-mail: tuuli.lahdesmaki@jyu.fi

Tel: +358 048053839

Funding acknowledgement:

The work has been supported by the Academy of Finland under Grant SA274295

(EUCHE) and the European Research Council under Grant 636177 (EUROHERIT).

Word count of the manuscript: 8844 


\title{
Narrativity and Intertextuality in the Making of a Shared European Memory
}

\begin{abstract}
The latest wave of European integration process, cultural Europeanization, includes complex processes, such as the attempts to create a shared European memory that would transcend national interpretations of the past. The cultural Europeanization can be perceived as a narrative operation: in it the EU, Europe, and Europeanness are given meanings and made sense of through narrativization. The article investigates the EU's attempts to create a shared European memory by analyzing the exhibition narrative of the Parlamentarium, the visitors' center of the European Parliament. The analysis indicates how the construction of an official shared European memory is operationalized through textual and narrative devices such as intertextuality and the pending narrative structure. I argue that the EU's memory texts are performative narratives which do not only describe a shared European memory in a particular way but also position the receivers as active agents in the story of the EU-Europe and invite them to produce it on their own initiative.
\end{abstract}

\section{Keywords}

European memory, European Union, intertextuality, narrative, Parlamentarium 


\section{Introduction}

In the past two decades, culture and cultural belonging have emerged as recurring topics and major areas of interest in the political discourses of the EU. The idea of a common culture in Europe has been included in the EU policy rhetoric since the Maastricht Treaty (1992), but the more explicit EU actions on shared heritage, history, and memory are, however, more recent. The EU interest in common culture and cultural belonging and the various policies and practices created to promote and govern them belong to the 'third wave' of the European integration process, brought out after the more or less realized waves of economic and political unification - that are, however, in the current European reality of severe economic and political crises more threatened than ever. The third wave, often defined as cultural Europeanization, includes complex and strongly disputed processes, such as the inculcation of a particular European amalgam of knowledge, attitudes, and values (Karlsson 2010, 38) and the attempts to create a shared European memory that would transcend national differences in the interpretation of the past (Jarausch 2010, 309-10; cf. Settele 2015). 
Various scholars have noted how the EU's recent 'move to history' is not lacking in political motives (e.g., Lähdesmäki 2014a; Prutsch 2013, 36). The quest for a common history and shared cultural roots aims not just at inspiring a more profound understanding of the European dimension of the past, but it also seeks to create a transnational memory that can legitimate further integration of the EU and its use of power for attaining its aims (Jarausch 2010, 310). Indeed, the EU's attempts for presenting the EU as a 'humanistic enterprise' based on shared values and common cultural features can be perceived as having functional utility. As Cris Shore (1993, 785-6) states, it is a tool for bringing the member states together and promoting the political legitimacy of the EU. The fundamental utility of representing the EU as a 'humanistic enterprise' is in its affective nature: the emphasis given on common history and culture and shared memory aims to appeal to people's feelings of belonging, sense of communality, and cultural and social attachments, thereby striving to justify the promotion of cultural integration in the EU (Lähdesmäki 2014b).

The idea of a shared European memory faces various challenges in today's Europe where global cultural flows and the movement of people within and across the EU borders have increased its inner pluralism, and where diverse nationalist and populist movements aim at creating or maintaining national cultural borders and object the ‘creolization' of cultures and the EU integration policies and practices (cf., Parkier and 
Stråth 2010; Settele 2015). This article investigates how the European Parliament as a political actor of the EU aims to create a shared European memory among people whose narrations of national histories, interpretations of past events in Europe, and notions on Europe itself differ greatly.

The EU memory initiatives are commonly put into practice by national, regional, and local level agents. So far, the EU's administrative bodies have themselves created only one public site — the Parlamentarium, the visitors' center of the European Parliamentfor displaying the 'official' story of the EU-Europe. The second public site of a European memory launched by the European Parliament-the House of European History-is currently under construction. In order to analyze in-depth the tactics and devices of producing an official shared European memory in the EU initiatives, the investigation was conducted as a case study by choosing the Parlamentarium for a closer examination.

The initiative for the Parlamentarium came from the Secretary General of the Parliament, Sir Julian Priestley, after his visit to Washington, DC. Priestley suggested setting up a visitors' center in Brussels similar to that on Capitol Hill (Writing for (y)EU 2011). The European Parliament made a decision on a visitors' center in 2005 after which Alexander Kleinig, an Austrian advisor to the Director General for External 
Affairs, was appointed its project manager. The center, named Parlamentarium, was opened in the Willy Brandt Building in the administrative block of the Parliament in Brussels in 2011. The center is spread over three floors and includes over 3000 square meters of exhibition space divided into six permanent and one temporary exhibition halls with a full range of visitor services including a shop, a cafeteria, and educational spaces for pupil groups. The design of the visitors' center was based on a plan by Atelier Brückner, a German company specialized in designing narrative architecture and spaces for brands, exhibitions, trade fares, and museums, which won a European-wide competition of invited submissions. The winning design was executed by the architects from Atelier Brückner in cooperation with various experts from German and Austrian graphic and media companies (E-architect 2011; Atelier Brückner 2011). The Parlamentarium is open every day free of charge and its information is available in all official EU languages and several European sign languages. The Parlamentarium has been an extremely popular sight in Brussels: in the beginning of 2015 it welcomed its one millionth visitor (Clapson 2015). As the web site of the European Parliament (EP 2015) states, in the Parlamentarium '[d]ynamic, interactive multimedia displays guide our visitors through the journey of European integration and the impact this has on our everyday lives.' The visitor policy of the Parlamentarium is to provide accessibility to all visitor segments. However, particular emphasis is given to children and youths: they 
are addressed with special tours, role-play games, hands-on applications, and informative material planned for teachers visiting the center with pupils.

The article approaches the Parlamentarium in the theoretical context of cultural and narrative turns in memory studies. In this context, memory has been localized within a broader framework of social and cultural practices and artefacts (Brockmeier 2002a; 2010; Pakier and Stråth 2010) and perceived as produced with cultural 'tools' that are available in a particular socio-cultural setting (Pakier 2010; Wertsch 2002). Therefore, a European memory constructed by the exhibition in the Parlamentium is perceived in this article as a cultural memory — a concept with which Jan Assmann (2000) and Aleida Assmann (2006) have referred to the deep cultural codes and myths of a society that act as the basis for the formation of memory. As Jens Brockmeier (2002b; 2010) notes, memories are 'transindividual' cultural creations which are made sense of through stories and are often materialized and objectified in for example monuments, museums, libraries, anniversaries, and landscapes. The material structures of cultural memory are embedded in the explanatory and interpretive discourses in which narratives play a crucial role (Brockmeier 2002b; 2010). The cultural aspect to memory thus emphasizes the intertwined nature of the past, present, 'truth', and stories (Lähdesmäki 2007, 409) and the agency of stories and narration in the workings of cultural memory. The focus of this article is thus on the story of the EU-Europe itself 
and its productive and performative nature-not on individual actors who have proposed, planned, or executed the story. Following the theories in narratology, the narrator of the story of the EU-Europe in the Parlamentarium is not perceived as a person but as a 'voice' (Genette 1972): rather than investigating who are the persons who have written the texts displayed in the exhibition, the analysis of the article focuses on 'focalization' (Genette 1972), i.e., the perspective through which the story is presented.

The narration of history is always an ideological act: in a historical narrative temporal continuity and causal relationship can be forged between fragmented and even unrelated events and phenomena. Narration is thereby a process of selecting meaningful elements and ordering them into a story which tells the plot in a particular way (cf. Bal 2009, 5). In the process of ordering the elements of the story, the complexity of the historical events is inevitably simplified and certain events are prioritized. The narrative nature of cultural memories constructs the past in a cumulative and episodic manner (cf. Schwartz 1990, 104). The exhibition narrative in the Parlamentarium emphasizes and repeats the selected 'key events' of 20th century Europe, such as the World Wars, setting up the Council of Europe and the European Community / Union, the collapse of Communist regimes, and signing various agreements which strengthen cooperation and integration 
in Europe. In the narrative, European memory turns into a continuation of historical turning points on which the remembering is cumulated.

The research data of the article consists of texts, images, and media guide information in the permanent exhibition halls of the Parlamentarium as well as the information provided on its web site and booklets. The data was investigated by adopting two concepts—narrativity and intertextuality—as methodological analytic tools and applying them not only to the analysis of textual but visual communication as well. Thus, the analysis also obeys the visual turn in memory studies by emphasizing the agency of the image in the formation of memory (cf. Guerin 2007). The core concept of the article_-intertextuality—has been defined by Julia Kristeva (1980) as a process of textual interaction in which each text is an intersection of other texts. This idea stems from Mikhail Bakhtin’s (1981) theory of 'dialogism', according to which all texts have traces of other texts within them and receivers are able to understand texts because of their connection to earlier patterns of meanings, utterances, or words. In this article, intertextuality is perceived as a semiotic device through which cultural meanings and their contexts are circulated in narrative processes. The point of view of the study frames the construction of European memory as a cultural project operationalized through a textual, intertextual, and narrative means. In this point of view 'culture' is understood as consisting of 'explicit and implicit patterns of historically derived and 
selected ideas and their embodiment in institutions, practices, and artifacts' (Markus and Hamedani 2007, 11). The empirical analysis of the study focuses on texts in the Parlamentarium and on the Parlamentarium itself as a text and the linguistic, semiotic, and performative dimensions of texts in the practices of memory. The concept of text is defined in the article in a broad Barthesian (Barthes 1973) sense that includes in the concept also visual representations, objects, and other meaningful units of semiotic systems (cf. Bal 2009, 10). As Mieke Bal (2009, 5) states, text is a finite, structured whole composed of signs—not only of language.

The article broadens the current study on the European Union by focusing on its memory politics and practices from the narrative point of view. The article begins with a contextualization of the recent attempts of creating an EU memory policy. The contextualization is followed by a brief theoretical discussion which focuses on the textual and narrative points of view in making sense of memory. The theoretical points of view are applied to a narrative analysis of the construction of official European memory in the Parlamentarium. The article ends with a discussion on the ideological dimensions of the EU memory policy and practices.

\section{European Memory in Political and Scholarly Discourses}


The idea of a shared memory has become a powerful vehicle for shaping the EU's identity policies (Littoz-Monnet 2012). In the EU policy discourses and memory initiatives, the attempts to add a transnational layer to the pre-existing national memories frequently stems from three points of reference (Prutsch 2013, 15). Firstly, the idea of a shared European memory is commonly built on the idea of a shared European heritage. However, the notion of European heritage in the EU policy discourses is extremely generic, abstaining from focusing on any particular cultural features. The notion is intentionally vague since explicit pronouncements on what makes a heritage 'European' might lead to conflicts and problems regarding the ownership of heritage and its national interpretations (Vos 2011, 226). In the recent EU heritage initiatives, the policy discourse aims for example to strengthen 'European citizens' sense of belonging to the European Union' on the basis of 'shared values and elements of European history' (EC 2011, 2-3) and to promote 'EU citizenship by preserving and facilitating access to historical sites of shared European memory' (EP 2012, 154). A common European heritage - defined through generic shared values and unspecified elements of history - functions in the policy discourse both as an indication of an existing shared memory and a source for European identity. 
Secondly, the EU policy discourses commonly align European memory with the development of the EU and the history of European integration: a European memory is easily paralleled with a narrative of the emergence, development, and functioning of the EU. Thirdly, the memory politics of the EU have had its most concrete focus on the two World Wars, the Holocaust, and the 20th century totalitarianisms. Preceded by initiatives since the 1990s, especially of the European Parliament, to increase awareness of the Holocaust, and with the EU's Eastern enlargement also of the crimes of the communist regimes, efforts regarding European memory politics were supported in particular by the European Commission's Europe for Citizens Programme which was launched in 2006 (Prutsch 2013, 6). In its current version, the significance of remembrance has even strengthened. In addition, the EU has in various other programs and initiatives paid attention to the memory of the crimes caused by the 20th century European totalitarianisms (EC 2010). For example, the European Parliament's Resolution on European conscience and totalitarianism in 2009 includes several actions that promote the remembrance of the victims of totalitarian and authoritarian regimes in Europe (EP 2010). The remembrance of the horrors of Europe's recent past serves a clear purpose in the EU's memory discourse: the 'appropriate preservation of historical memory, a comprehensive reassessment of European history and Europe-wide recognition of all historical aspects of modern Europe will strengthen European integration' (EP 2010, 27). This kind of European-wide ‘politics of recognition' and 
understanding of history with 'all' its aspects is believed to have an impact on the European integration process.

The 20th century European totalitarianisms and their policies embody an absolute contrast to the immanent ideals, such as peace, freedom, democracy, the rule of law, human rights, civil liberties, the right to individual self-determination, and pluralism, commonly embraced in the political discourses of the EU. The remembrance of the horrors of 20th century Europe, such as the combats of the World Wars, the Holocaust, Stalinist crimes, and Communist terror, thus forms an extremely negative foundation myth for the EU (Prutsch 2013, 26, 35-6).

Besides the policy discourse, the scholarly literature has commonly brought out the World Wars as the unifying phenomena of Europe's past (e.g., Delanty 2002; Niznik 2013; Pakier and Stråth 2010). However, several historians, philosophers, and sociologists (e.g., Niznik 2013; Svoljsak 2013; Škrlj 2013; Troebst 2010; Jarausch 2010; Karlsson 2010) have emphasized how the World Wars are remembered in very different ways in different European countries. The historical memory is still strongly attached to national contexts, as Józef Niznik $(2013,10)$ notes. The variety of memories and their national contexts and meanings make the construction of a shared European memory extremely challenging. 


\section{Narrating European Memory in the Parlamentarium}

Memories are created, transformed, and institutionalized through narrativization and materialization of stories. The recent modes of theorization and conceptualization of memory in scholarly literature have emphasized language use, textuality, visuality, discursivity, and narrativity in meaning making processes. These theoretical approaches have also brought out language as a research tool, which has led to new modes of talking about the objects of research and the creation of new concepts in order to make sense of them. Several scholars have emphasized memory as a textually mediated act intermingled with language in its manifold oral, written, and performative forms (Wertsch 2002; Brockmeier 2010; Pakier 2010) and noted that it follows the logic of narrativization. Although the narrative approach has been common in the studies of autobiographical memories (e.g., Brockmeier 2009; Cabillas 2014; Monchamp 2011), the processes of narration and narrative structures can be perceived as embedded into all practices of cultural memory, such as the production of official memory.

The narrative approach enables the theorizing and analyzing of memory practices with the help of concepts adopted from linguistic and textual research. A core concept 
adopted from linguistic and textual research in the analysis of the data in this article is intertextuality, which can be perceived as an important mnemonic device and an effective strategy of producing cultural memory (Lähdesmäki 2007, 418; Neumann 2008, 335). Some scholars in literary studies have even used the concept of intertextual memory to describe the allusions and references to other stories and historical myths found in the investigated narratives (Cantú 2001; Rickard 1998; Smith 2004). The power of intertextuality in memory practices rises from the use and circulation of already existing and culturally shared texts and imagery connected to the object of remembrance (Lähdesmäki 2007, 421-2). Indeed, intertexts operate through recollection: when people 'hear' a story or a story fragment, they also 'hear' echoes of other stories (Mageo 2001, 12). The context of texts and images influences their new uses through intertexts. Intertextuality generates the repetition of certain texts and images, increases their familiarity, and produces a feeling of temporal continuity. Intertextuality can thus be perceived as a memory strategy which participates in the ordering of what is 'worth remembering' and framing the 'worth remembering' with certain narratives and representations.

When the manifestations of cultural memory-or memory texts-are understood as narratives, their structural and functional logic are perceived to follow that of narration. The distinct narrative orders-the linguistic, the semiotic and the discursive / 
performative-participate in the construction of meanings in memory texts (Brockmeier 2002a). Together the orders constitute a mnemonic system, a symbolic space of remembering and forgetting, in which the past and present are continuously recombined. What follows is an investigation on how the narrative orders function in the construction of official European memory in the Parlamentarium.

The Linguistic Order of European Memory

The linguistic order of narratives refers to a combination of various elements, such as scene, agents, action, intentionality, predicament, and solution, which are the constituents of a narrative proper and which encapsulate the plot of the story (Brockmeier 2002a, 33). The exhibition in the Parlamentarium constructs a narrative proper using numerous textual elements. Indeed, even the 'objects' in the exhibition are texts, such as the replicas of historical documents of the EU that are considered as turning points in the European integration process. The exhibition starts in a hall named 'Prologue' — which itself is a narrative concept. The hall introduces the agents of the story in the Parlamentarium: the citizens of the EU and the administrative bodies of the EU. The citizens are introduced as a soundscape in the 'Tunnel of Voices' in which the different official languages of the EU can be heard. In addition, the hall includes various 
information boards which aim to display the positive impact of the EU on the everyday life of Europeans in different languages. The hall ends with a space that introduces the main protagonist of the story: the European Parliament. The space contains models of the administrative buildings of the Parliament in Brussels, Strasbourg, and Luxembourg and information which explains their functioning. In addition, a broadsheet on the wall introduces the buildings of the European Commission and the Council of the European Union in Brussels.

The 'Prologue' is followed by 'Visions' located in a long black aisle divided by two narrative devices. The wall on the right exhibits images of the horrors of Europe's 20th century civil and World Wars, starting with a picture depicting the feeding of poorly dressed hungry children orphaned in 1919 by the Finnish civil war. The visual narration proceeds from images of war to images of the aftermath of the World War II with the focus on the clearing of damages in European cities and ending with an image of a signature of the Statute of the Council of Europe in 1949 in London. The wall on the left contains screenings of text fragments quoting writings and speeches of various 20th century European politicians and intellectuals appealing for peace, humanity, and the unity of Europe. In several quotations, the culprit to the horrors exhibited on the opposite wall is found in nationalism and nation-states, such as the quotation from The Ending of Armageddon, 1939, by Philip Henry Kerr demonstrates: 
...national sovereignty is the root cause of the most crying evils of our time and of the steady march of humanity back to tragic disaster and barbarism...The only final remedy for this supreme and catastrophic evil of our time is a federal union of the peoples...

Through the image wall the 'Visions' hall outlines the European predicament crucial to the story of the EU-Europe, while the opposite wall introduces the key solution to it, brought out in several fragmented quotations such as in the excerpt from Józef Retinger's letter to Denis de Rougement written on March 1948:

As you know, I am very strongly in favour...to announce the declaration..., which will define the cultural and spiritual background of our gathering and our joint activities. I visualize it as a sort of manifesto, a directive to all men of good will, interested in peace and prosperity of Europe, which can only be achieved through the Unity of Europe.

The narrative devices of the 'Visions' present the European unification as the only solution to end the suffering of people in Europe. Simultaneously, the narrative introduces the 'forefathers' of the EU and frames them as visionary heroes in the story. 
The 'Visions' is followed by a hall named 'Beginnings' which continues the chronologically proceeding time frame of the narrative and relies on narrative devices similar to the previous hall. The wall on the left is covered with 150 iconic images that 'represent events which have helped change the face of Europe' (Parlamentarium booklet, 2014). The image wall, starting with photos depicting Warsaw ruined in bombings, the Birkenau gate, and a Russian soldier raising the Soviet flag over the Reichstag, and proceeding through the decades up until the present decade, brings out imagery familiar from popular history. The images display, e.g., Atomicum in Brussels, Kennedy's visit to Europe, a famous movie scene at the Trevi Fountain from La Dolce Vita, but also more recent scenes, such as travel by Eurostar train. Many of the exhibited images are well-known press photos depicting the turning points of national histories in the second half of the 20th century, such as various revolts and protests against the Communist regimes in Europe. These images depict, e.g., the Baltic Chain, the Pan-European Picnic (the opening of one of the frontier barriers on the AustroHungarian border), and the fall of the Berlin wall. The exhibition narrative utilizes the familiarity of the images in the creation of a common European memory by fixing them as elements of broader transnational history. 
Roland Barthes (1977, 39-41) has used the term 'anchoring' to describe a meaningmaking process in which a text-a verbal anchor-attached to an image foregrounds certain meanings and lifts up some features in the image as essential while leaving others in the background. The images in the 'Beginnings' do not include any explanatory captions and thus the image wall gets its meaning through verbal anchors attached to it elsewhere in the hall: the visualization of the 'key events' in European and national histories is juxtaposed to the development of the EU and the deepening European integration introduced in detail on the information tables in the hall. By anchoring the provided textual information to the images, the exhibition narrative represents the development of the EU and the transformation of the European countries and their liberation from the fascist, Nazi, and communist regimes as a causal relationship. In general, the exhibition narrative in the 'Visions' and 'Beginnings' underlies the power of text: the forefathers of the EU presented their visions in writing and talking and the visions were realized by creating and signing agreements on European-wide collaboration.

The historical timeline in the Parlamentarium's exhibition narrative ends with a big ticking clock on the back wall of the 'Beginnings' hall. The visitors descend beneath the clock into a hall named 'Tomorrow and Today', in which the exhibition narrative demonstrates the successful result of the European integration process: the Nobel Prize 
medal and certificate given to the EU in 2012 are exhibited in the middle of the room. In the same room, all members of the European Parliament are introduced on the walls, emphasizing their role as peacemakers in the story of the EU-Europe.

The exhibition narrative emphasizes the present and the future of Europe as following the idea of the official EU slogan-united in diversity. The hall following 'Tomorrow and Today' is named after the slogan. The hall brings out a teleological understanding of the European past: the historical attempts for deepening the European integration and overcoming the obstacles hindering the free movement of people and goods in Europe introduced in the previous rooms are represented in the hall as having been successful and transformed the contemporary European reality. The floor of the hall is covered with a European map in which the only territorial markings pinpoint cities that host EU agencies or offices. Moving on the map functions as an educational game: 'Portable scanners act as media guides allowing visitors to travel to a county or region of interest and find out exactly what European Union projects, agencies or headquarters exits within the 28 Member States' (Parlamentarium booklet, 2014). The idea of free movement in Europe is combined in the hall with the familiarization of the functioning of the union. 
The 'United in Diversity' hall joints two smaller exhibition spaces called 'Daily Life' and 'A Parliament for Europe'. In 'Daily Life' a series of short films tell the stories of 54 Europeans 'who explain how the EU and its policies have had an impact on their lives, their business and their projects' (Parlamentarium booklet, 2014). In 'A Parliament for Europe' visitors can take a seat at a round table and get an impression of participating in EU decision-making while watching a short film that explains how the European legislative process works projected on a $360^{\circ}$ screen surrounding them. The exhibition narrative in these halls presents European daily life and the EU administration as closely intertwined: daily life stories bring out a bottom-up support for the master narrative in the Parlamentarium and introduction of the European legislative process presents the EU institutions as having a major top-down influence on European daily life. The map of Europe and the set in the 'A Parliament for Europe' demonstrate scenes where the story of the EU-Europe takes place in the exhibition narrative. In the end of the narrative, the citizens of the EU, including the visitors to the Parlamentarium, are again brought out as characters in the story of the EU-Europe. The exhibition ends with a hall named 'Wishes for the future' in which the visitors' greetings and views on Europe and the EU are reflected on the walls.

The Semiotic Order of European Memory 
Narrative texts are laid out along storylines which reflect broader textual and narrative contexts, such as myths. The semiotic order of narratives refers to these contexts as particular sign systems through which the narratives are formed and get their meanings (Brockmeier 2002a, 34). The narrative modes existing in cultural contexts set the limits to the ways the past is and can be remembered in memory texts (cf. Brockmeier and Carbaugh 2001, 3; Middleton and Edwards 1990, 4-5). One of the hegemonic modes of remembering the past stems from the national history writing. National histories and their storylines have a crucial role in structuring the understanding of the past in Europe: the elements recurring in national memories function as the context for the EU's attempts to narrate a shared European memory.

The exhibition narrative in the Parlamentarium constructs a European memory from the elements commonly used in nation-building projects by highlighting the historical turning points, symbolical monuments, mythical objects, exemplary forefathers, and cultural achievements of the community. In national narratives, the canonizing of the so-called Great Men has been a typical strategy in the attempts to reinforce national self-esteem and to create an image of a civilized society (Hobsbawn 1983, 270-6). In the Parlamentarium, the quotations reflected on the wall in the 'Visions' hall participate in the construction of a European canon of Great Men: among the politicians and 
intellectuals expecting a closer unification of Europe are Winston Churchill, Józef Retinger, and Seán MacBride. In addition, the exhibition narrative highlights 12 cultural or scholarly significant Europeans: William Shakespeare, Wolfgang Amadeus Mozart, Victor Hugo, Franz Liszt, Giuseppe Verdi, Marie Skłodowska Curie, Albert Einstein, James Joyce, Pablo Picasso, Franz Kafka, Maria Callas, and Astrid Lindgren, all of whom are presented in separate stands around the exhibition space. These artists and scientists are represented as pan-European cosmopolites who spoke several languages, travelled or worked in various European countries and/or had a broad influence on the European cultural or academic scene. Many of the artists and scholars are introduced as promoters of European unification and integration: 'A pacifist and member of the PanEuropean movement, Albert Einstein spoke out in defense of what he called 'European civilization' and predicted Europe's eventual unification' and 'A strong believer in European integration, Hugo took part in the International Peace Congress in Paris in 1849, where he called for the creation of a United States of Europe'. By emphasizing the forefathers of the EU and the 'European Great Men', the official European memory in the Parlamentarium stems from the attempts of rebuilding a narrative which has lost its validity and become outdated at the national level during the past 40 years.

The exhibition narrative of the Parlamentarium is told as a founding story of the EUEurope. It follows the storyline of various founding myths: a brighter and better world 
emerges from destruction. The theme of war is a central and recurring semiotic marker in the exhibition narrative: like a phoenix the peaceful, democratic, and unified Europe is reborn from the ashes of bombed and burned European cities. In addition to the founding story, the theme of war frames the story of the EU-Europe as a teleological salvation story. In it the main agent of the story, the EU and its fore and founding fathers, saves the fragile and beaten Europe from perdition by creating a union which brings all Europeans together. This brave deed of the main agent is finally rewarded with the highest possible award: the Nobel Peace Prize. The teleological story displays the setting up of the EU and the strengthening of European integration as ineluctable incidents. Teleologism of the narration induces its receivers to perceive the political attempts of the main agent as having no alternative.

In the narration, which projects causal relations between historical events, transformations are often interpreted as unavoidable and wanted for (Lähdesmäki 2007, 411-2). In this kind of teleological explanation of history, each event is narrated as an outcome of the previous event and leading inevitably to the next one. The teleological narration of the past is a particularly common strategy for making sense of historical conflicts. Conflict situations are often afterwards narrated as a struggle for the unity of the community: the narration aims at building consensus within the present community (Bodnar 1992, 206). The dramatic events, such as wars, are difficult to recount without 
mythologizing the characters, scenes, and turning points of the story. The narration of dramatic events brings out some characters as heroes, some as victims, and some as villains of the story. Mythical stories often overtake events or storylines that are complex, contradictory, or sensitive. Silencing difficult memories is a strategy to construct consensus and communality: uncontroversial remembering creates an impression on the unity of the community and its shared experiences (cf. Halbwachs 1992, 182-3; King 1999, 164). The consensus can also be created by drawing attention from present day tensions to historical conflicts. The exhibition narrative of the Parlamentarium aims to create consensus by smoothing over or remaining silent about various current struggles, such as the rise of radical right-wing parties and movements, nationalist and regionalist claims, religious and ethnic tensions, Euroscepticism, and economic crises in Europe, and conflicts that have taken place in the suburbs of European cities during the past decade.

The exhibition narrative in the Parlamentarium is constructed from a broad body of written and visual intertexts. The 'iconic' photos and quotations from various texts function as evidence for the 'truthfulness' of the exhibition narrative. Intertextuality produces the repetition of certain selected memories: through repetition selected memories are established as 'truths'. Intertextuality and repetition thus create blindness to the constructed nature of narratives and conditions to perceive the world in a 
particular way. Simultaneously, the receivers' expectations for particular kinds of cultural meanings and modes of representation increase. When memory texts follow commonly repeated and broadly circulated narratives and imageries, such as in the case of the Parlamentarium bringing to the fore the tropes of war, emergency resulting from its destruction, and liberation from totalitarianism, and link these tropes to the story of European integration, the need for explaining and justifying them decreases: memory texts are perceived as bringing to the fore history 'as it happened'.

The repetition and republishing of images in memory texts gradually depletes images from their indexical references to the events they depict. Instead, repeated images become more and more linked to their prior uses, turning them into signs that signify by social convention. Thus, e.g., images depicting civil protests against the Communist regimes and the fall of the Berlin wall easily turn into visual signs of democracy, freedom, and integration in the narration of a European memory. The process of abstraction of the indexical reference of images and their canonization in cultural narratives coincide and mutually reinforce each other, since the more the unambiguous and symbolical meanings of an image are consolidated, the more likely it is to be used and circulated in cultural narratives. Through repetition an image can turn into a visual token, a mnemonic that stands for an event as a whole, a series of events, or even a certain phase of history (Ruchatz 2008, 375). The images in the Parlamentarium have a 
symbolic function: they signify the salvation story of the EU-Europe and its founding myth.

The Performative Order of European Memory

A narrative is not only a structure of meaning or a product of narration-a story — but also a process of telling and a performance of meaning. Narratives are functional actions which unfold an objective; they have a goal and aim to do something. Narrated events or historical 'facts' as such do not constitute a plot or entail a meaning, which is produced in the discursive practices of their presentation. The discursive practices activate the performative nature of narratives and turn them into agents in a cultural system (Brockmeier 2002a, 35). This discursive or performative order of narratives gives them their power to influence the meanings, values, and knowledge within a sign system.

The exhibition narrative in the Parlamentarium has an action-orientated aim: the discursive practice of the narrative stems from the third wave of the European integration process aiming to produce a European identity and a feeling of belonging to the EU-Europe. In the Parlamentarium, the European identity is not framed as a 'thin' 
civic identity based for example on the legal agreements and citizenship status, but the exhibition introduces it as a 'thick' cultural identity built on shared history, heritage, memory, and values. Building the European identity as a thick cultural identity faces challenges due to the strong bonds between history, heritage, cultural memory, and national narratives. In addition, the emphasis on history and heritage is an extremely exclusive strategy for building the European identity: it excludes those who do not share the same cultural and historical roots. However, the emphasis on culture, history, and heritage in the Parlamentarium can be interpreted as having a functional utility: they function as affective instruments in creating a sense of common belonging.

The exhibition narrative of the Parlamentarium fixes the visitors as active agents in the founding story of the EU-Europe. The visitors are carried through the exhibition halls guided by portable media-guides directing them to search for more information of the exhibited images and documents. The halls downstairs contain diverse interactive polls on various issues studied in the Eurobarometer and European Value Surveys and discussed and voted on by the European Parliament. The results of the visitor polls and surveys and the views of the parliament are illustrated on the 'Result Ceiling' and a massive Europe-shaped overhead LED display called the 'Sky of Opinions'. Through the polls the visitors are practically engaged in the 'European project': visitors are positioned to perceive themselves as the European demos. During the past four years, 
the Parlamentarium has turned into a tourist attraction in which masses participate, on their own initiative, in a joint remembering exercise.

The exhibition narrative of the Parlamentarium engages the visitors with its textual structure which can be described as a pending narrative. The crucial feature in a pending narrative is its openness in the momentum for action: when the motivation for the action has been created, the story is interrupted. The pending narrative is thus a future-oriented and persuasive story form. It aims at motivating the audience outside the text to take action and constructs for it a specific subject position in relation to the action set forward. The pending narrative is a semiotic macrostructure commonly used in political texts for making the unknown, uncertain, or threatening future more predictable and controllable. It enables the channelling of the receivers' interests and desires toward a shared goal by instructing them how to interpret the threatening situation and by demonstrating how the desired end-result can be achieved (Törrönen 2000, 83, 96; 2010, 307). The ticking clock in the Parlamentarium functions as a break in the historical founding story of the EU-Europe. It is a turning point in the narrative after which the continuation of the story is left open. Simultaneously, it functions as a performative invitation for the visitors to take the position of an active agent in the story - however, it can only be taken within the discursive frame used in the exhibition narrative before the break. The pending structure emphasizes the ideological and 
political message of the exhibition narrative: the deepening of the European integration is represented as the only way to continue the story.

\section{Conclusions}

The production of memories is an act of power which is commonly used by those who hold or aim to hold the power in a society. Official memory is officially supported and promoted by those in power (Jović 2004) and is created for a purpose of stabilization of the status quo in a society (Bodnar 1992), although it commonly claims to have collective meanings. Since memory is an act of power, memory politics is not immune to struggles over it. Forces of power can also be counteracted and official memory challenged by counter-memories (Wertsch 1998). The Parlamentarium is an example of the EU-level attempts to create an official European memory: it underlines the political aims of the union by connecting milestones in the political and integration history of the EU, the key political ideas promoted in the current EU policy discourse, and selected texts and images depicting the European past and present. In the story, the explicit and implicit narrative 'voice' belongs to the European Parliament as a representative of the EU's institutional power but also to a more general, ambiguous and undefined institutional agency; the EU. The EU's memory texts are performative narratives which 
not only describe a shared European memory in a particular way but also position the receivers as active agents in the story of the EU-Europe and invite them to produce it on their own initiative.

Cultural initiatives function as political building blocks which the EU uses in its attempts to deepen cultural integration in Europe. The ultimate goal of these attempts is in the creation of a common European cultural identity. The EU's identity project is a top-down attempt but it aims to activate bottom-up participation, that is, to produce selfcreating identification to the EU-Europe fostered by Europeans. The EU's identity project relies on elements familiar from nation-building projects, such as the construction of shared memory and the founding narrative of the nation. The EU's identity project and the construction of a shared European memory are political attempts, formed in relation to their nation-level counterparts. Strong national identities, national cultural memory, and national narration of history are often perceived in the EU policy rhetoric as threats or problems to be tackled with the means of the EU cultural initiatives that transcend the nation-level interpretation of history and cultural elements (Lähdesmäki 2014b, 78-9; 2014a, 408-9).

An official shared European memory is made in language and through texts. As Thomas Diez (2001, 88) argues, the history of the EU, with its agreements, declarations, 
directives, and decisions, can be perceived as a broad collection of speech acts. The EU memory texts, such as its resolutions focusing on remembrance, initiatives fostering a common heritage and history, and sites telling the story of the EU-Europe, like the Parlamentarium, are performative speech acts (Austin, 1982) which frame, name, label, and narrate phenomena as shared European memory.

The performative dimension of a European memory is intertwined with the European identity project. A European cultural identity is created in the EU's memory texts, such as in the Parlamentarium, on the basis of recognition of the European memory as 'ours'. Visitors to the Parlamentarium are expected to identify with the European memory narrated in the exhibition and to participate in its production by recognizing it as 'shared'. Indeed, visitors to the Parlamentarium have a crucial role in the construction of a European memory: their contribution is a part of the design of the exhibition, and they are therefore fueling the narrative engine that is articulating the memory as European and shared.

The third wave of the European integration process can be perceived as a linguistic and narrative wave: in it, the EU, Europe, and Europeanness are defined and made sense through narrativization. The meanings of Europe have been recently rethought and renarrated in various cultural projects funded by the EU, such as the pilot project ' $\mathrm{New}$ 
Narrative for Europe' launched by the European Commission in 2013. The EU's attempts to create cultural integration in Europe effectively utilize intertextuality in its narrative practices. Intertextual references involve the repetition of certain texts and images and their narrative contexts, create familiarity with them, and enhance the feeling of continuity — and thus have an important role in producing and establishing cultural memories. Intertextuality institutionalizes myths and establishes what is perceived as 'true', 'right', and 'proper'. The analysis of the exhibition in the Parlamentarium indicates how the teleological foundation story of the EU-Europe is narrated through intertextual references. The story represents itself as 'true' since it is composited of 'true' texts and images that are familiar to many people from other contexts.

Various scholars (Pakier and Stråth 2010; Prutsch 2013) have emphasized the problematic nature of the idea of a shared European memory since national memories in Europe are diverse and often contradictory. A shared memory presupposes a real or an imagined community which shares the memories. Is there an emerging European community of remembrance in Europe? Małgorzata Pakier and Bo Stråth $(2010,13)$ claim that 'the answer is most often in the negative'. However, there seems to be a community, which perceives the fostering of a shared European memory as extremely important and which actively creates memory practices to promote the communality of 
the community. The EU with its administrative bodies is a community of remembrance which fosters its own identity through narrating selected cultural phenomena, heritage, historical events, and memories as European. Various EU memory texts, such as the Parlamentarium, are affective invitations to join the EU community of remembrance. Textual structures, such as a pending narrative and intertextuality, function as a means to persuade Europeans to this community.

\section{References}

Atelier Brückner. 2011. Parlamentarium. http://www.atelierbrueckner.com/en/projects/parlamentarium.

Assmann, A. 2006. "Memory, individual and collective." In The Oxford Handbook of Contextual Political Analysis, edited by R. E. Goodin and C. Tilly, 210-224. Oxford: Oxford University Press.

Assmann, J. 2000. Religion and Cultural Memory. Ten Studies. Stanford: Stanford University Press. 
Austin, J. L. 1982. How to Do Things with Words. The Williams James Lectures Delivered at Harvard University in 1955, edited by J. O. Urmson \& M. Sbisà. New York: Oxford University Press.

Bakhtin, M. 1981. The Dialogic Imagination: Four Essays, edited by M. Holquist. Austin: University of Texas Press.

Barthes, R. 1973. “Texte (théorie du).” Encyclopaedia Universalis 15, 1013-1017. Paris: Encyclopaedia Universalis.

Barthes, R. 1977. Image-Music-Text. London: Fontana.

Bodnar, J. 1992. Remaking America. Public Memory, Commemoration, and Patriotism in the Twentieth Century. Princeton: Princeton University Press.

Brockmeier, J. 2002a. "Remembering and forgetting: Narrative as cultural memory.” Culture and Psychology 8(1): 15-43.

Brockmeier, J. 2002b. Introduction: Searching for cultural memory. Culture and Psychology 8 (1): 5-14. 
Brockmeier, J. 2009. "Stories to remember: Narrative and the time of memory." StoryWorlds: A Journal of Narrative Studies 1 (1): 115-132.

Brockmeier, J. 2010 “After the archive: Remapping memory.” Culture and Psychology 16 (1): 5-35.

Brockmeier, J., and D. Carbaugh. 2001. "Introduction.” In Narrative and identity. Studies in Autobiography, Self and Culture, edited by J. Brockmeier and D. Carbaugh, 1-22. Amsterdam: John Benjamins.

Cabillas, M. 2014. "Memories under construction: Writing, narratives and dialogues.” Culture and Psychology 20 (3): 308-329.

Cantú, R. 2001. “Borders of the self in Alfredo Véa’s The Silver Cloud Café.” Studies in 20th \& 21st Century Literature 25 (1): 210-245.

Clapson, C. 2015. "Parlamentarium is one of Brussels' top attractions." $\begin{array}{llll}\text { FlandersNews.Be, } & 17 & \text { February } & 2015 .\end{array}$ http://deredactie.be/cm/vrtnieuws.english/News/1.2211187. 
Delanty, G. 2002. "Models of European identity: Reconciling universalism and particularism.” Perspectives on European Politics and Society 3 (3): 345-359.

Diez, T. 2001. “Speaking 'Europe': The politics of integration discourse.” In The social construction of Europe, edited by T. Christiansen, K. E. Jörgensen, and A. Wiener, 85100. London: Sage.

E-architect. 2011. Parlamentarium Brussels: European Parliament Visitor Centre. http://www.e-architect.co.uk/belgium/parlamentarium-brussels.

EC. 2010. The memory of the crimes committed by totalitarian regimes in Europe. Report from the Commission to the European Parliament and to the Council (COM(2010) 783 final). Brussels: European Commission.

EC. 2011. Decision No 1194/2011/EU of the European Parliament and of the Council of 16 November 2011 Establishing a European Union Action for the European Heritage Label. Official Journal of the European Union L 303: 1-9. 
EP. 2010. European Parliament resolution of 2 April 2009 on European conscience and totalitarianism (P6_TA(2009)0213). Official Journal of the European Union C 137 E: $25-27$.

EP. 2012. Parliament's position on the 2011 draft budget as modified by the Council all sections (P7_TA(2010)0372). Official Journal of the European Union CE 70: 149161.

EP. 2015. European Parliament. Parlamentarium. http://www.europarl.europa.eu/visiting/en/visits/parlamentarium.html.

European Parliament. 2014. Parliamentarium. Booklet.

Genette, G. 1972. Figures III. Paris: Éditions du Seuil.

Guerin, F., ed. 2007. The Image and the Witness: Trauma, Memory and Visual Culture. New York: Columbia University Press.

Halbwachs, M. 1992. On Collective Memory. Chicago: The University of Chicago Press. 
Hobsbawm, E. 1983. "Mass-producing traditions: Europe, 1870-1914." In The Inventing Traditions, edited by E. Hobsbawm and T. Ranger, 263-307. Cambridge: Cambridge University Press.

Jarausch, K. H. 2010. "Nightmares or daydreams? A postscript on the Europeanisation of Memories." In A European Memory? Contested Histories and Politics of Remembrance, edited by M. Pakier and B. Stråth, 309-320. New York: Berghahn Books.

Jović, D. 2004. “'Official memories’ in post-authoritarianism: an analytical framework.” Journal of Southern Europe and the Balkans Online 6 (2): 97-108.

Karlsson, K-G. 2010. "The uses of history and the third wave of Europeanisation.” In $A$ European Memory? Contested Histories and Politics of Remembrance, edited by M. Pakier and B. Stråth, 38-55. New York: Berghahn Books.

Kristeva, J. 1980. Desire in Language: A Semiotic Approach to Literature and Art, edited by L. S. Roudiez. New York: Columbia University Press. 
Lähdesmäki, T. 2007. Kuohahdus Suomen kansan sydämestä. Henkilömonumentti diskursiivisena ilmiönä 1900-luvun lopun Suomessa. Jyväskylä: University of Jyväskylä.

Lähdesmäki, T. 2014a. “The EU’s explicit and implicit heritage politics.” European Societies 16 (3): 401-421.

Lähdesmäki, T. 2014b. “Transnational Heritage in the Making. Strategies for Narrating Cultural Heritage as European in the Intergovernmental Initiative of the European Heritage Label.” Ethnologica Europaea 44 (1): 75-93.

Littoz-Monnet, A. 2012 “The EU politics of remembrance: Can Europeans remember together?” West European Politics 35 (5): 1182-1202.

Mageo, J. M. 2001. “On memory genres. Tendencies on cultural remembering.” In Cultural Memory: Reconfiguring History and Identity in the Postcolonial Pacific, edited by J. M. Mageo, 11-33. Honolulu: University of Hawai’i Press. 
Markus, H. R. and M. G. Hamedani. 2007. “Sociocultural Psychology. The Dynamic Interdependence among Self Systems and Social Systems.“ In Handbook of Cultural Psychology, edited by S. Kitayama and D. Cohen, 3-39. New York: The Guilford Press.

Middleton, D., and D. Edwards. 1990. “Introduction.” In Collective Remembering, edited by D. Middleton and D. Edwards, 1-22. London: Sage.

Monchamp, A. M. 2011. “The other side of the story.” Memory Studies 4 (1): 53-62.

Neumann, B. 2008. “The Literary representation of memory.” In A Companion to Cultural Memory Studies, edited by A. Erll and A. Nünning, 333-344. Berlin: Walter de Gruyter.

Niznik, J. 2013. "Preface. The social instruments of European memory.” In Twentieth Century Wars in European Memory, edited by J. Niznik, 9-17. Frankfurt: Peter Lang.

Pakier, M. 2010. “A Europeanisation of the Holocaust memory?” In A European Memory? Contested Histories and Politics of Remembrance, edited by M. Pakier and B. Stråth B, 191-203. New York: Berghahn Books. 
Pakier, M., and B. Stråth. 2010. “Introduction. A European memory?” In A European Memory? Contested Histories and Politics of Remembrance, edited by M. Pakier and B. Stråth B, 1-20. New York: Berghahn Books.

Prutsch, M. J. 2013. European Historical Memory: Policies, Challenges and Perspectives. Directorate-General for Internal Policies. Policy Department B: Structural and Cohesion Policies. Culture and Education. Brussels: European Parliament.

Rickard, J. S. 1998. Joyce’s Book of Memory: The Mnemotechnic of Ulysses. Durham: Duke University Press.

Ruchatz, J. 2008. “The photograph as externalization and trace.” In A Companion to Cultural Memory Studies, edited by A. Erll and A. Nünning, 367-378. Berlin: Walter de Gruyter.

Schwartz, B. 1990. "The reconstruction of Abraham Lincoln." In Collective Remembering, edited by D. Middleton and D. Edwards, 81-107. London: Sage. 
Settele, V. 2015. “Including exclusion in European memory? Politics of remembrance at the House of European History.” Journal of Contemporary European Studies, Published online: 09 Mar 2015. http://dx.doi.org/10.1080/14782804.2015.1018877.

Škrlj, K. 2013. "Sites of Memory, Sites of Mourning” or Landmarks: the Case of WWI Memory on the Border of Slovenia and Italy. In Twentieth Century Wars in European Memory, edited by J. Niznik, 217-230. Frankfurt: Peter Lang.

Smith, K. R. 2004. "Recollecting wondrous moments: Father Pushkin, Mother Russia, and intertextual memory in Tatyana Tolstaya's 'Night' and 'Limpopo'.” Studies in 20th \& 21st Century Literature 28 (2): 478-506.

Svoljsak, P. 2013. Slovenian Historiography and Collective Memory of the World War I in the First Yugoslavia (1918-1941). In Twentieth Century Wars in European Memory, edited by J. Niznik, 205-216. Frankfurt: Peter Lang.

Törrönen, J. 2000. "Passionate text. The pending narrative as a macrostructure of persuasion.” Social Semiotics 10 (1): 81-98. 
Törrönen, J. 2010. “On the road to serfdom? An analysis of Friedrich Hayek’s sociopolitical manifesto as a pending narrative.” Social Semiotics 13 (3): 305-320.

Troebst, S. 2010. "Halecki revisited. Europe's conflicting cultures of remembrance.” In A European Memory? Contested Histories and Politics of Remembrance, edited by M. Pakier and B. Stråth B, 56-63. New York: Berghahn Books.

Wertsch, J. V. 1998. Mind as action. Oxford: Oxford University Press.

Wertsch, J. V. 2002. Voices of Collective Remembering. Cambridge: Cambridge University Press.

Writing for (y)EU. 2011. "Parlamentarium-Interactive, Multimedia, Multilingual” http://www.ep-webeditors.eu/2011/10/parlamentarium-interactive-multimediamultilingual/.

Vos, C. 2011. “Negotiating Serbia’s Europeanness. On the formation and appropriation of European heritage policy in Serbia.” History and Anthropology 22 (2): 221-242. 